\title{
Human Taste Thresholds Are Modulated by Serotonin and Noradrenaline
}

\author{
Tom P. Heath, ${ }^{1}$ Jan K. Melichar, ${ }^{2}$ David J. Nutt, ${ }^{2}$ and Lucy F. Donaldson ${ }^{1}$ \\ ${ }^{1}$ Department of Physiology and 2 Psychopharmacology Unit, University of Bristol, Bristol BS8 1TD, United Kingdom
}

Circumstances in which serotonin (5-HT) and noradrenaline (NA) are altered, such as in anxiety or depression, are associated with taste disturbances, indicating the importance of these transmitters in the determination of taste thresholds in health and disease. In this study, we show for the first time that human taste thresholds are plastic and are lowered by modulation of systemic monoamines. Measurement of taste function in healthy humans before and after a 5-HT reuptake inhibitor, NA reuptake inhibitor, or placebo showed that enhancing 5 -HT significantly reduced the sucrose taste threshold by $27 \%$ and the quinine taste threshold by $53 \%$. In contrast, enhancing NA significantly reduced bitter taste threshold by $39 \%$ and sour threshold by $22 \%$. In addition, the anxiety level was positively correlated with bitter and salt taste thresholds. We show that 5-HT and NA participate in setting taste thresholds, that human taste in normal healthy subjects is plastic, and that modulation of these neurotransmitters has distinct effects on different taste modalities. We present a model to explain these findings. In addition, we show that the general anxiety level is directly related to taste perception, suggesting that altered taste and appetite seen in affective disorders may reflect an actual change in the gustatory system.

Key words: taste; chemosensory; serotonin; noradrenaline; anxiety; depression

\section{Introduction}

Taste is an important protective sense, evolved to drive food intake and aid in the avoidance of poison. The principal determinants of taste threshold are genetic, and taste thresholds do not vary considerably from day to day. This has lead to the concept of "non-tasters" and "supertasters" (Bartoshuk, 2000), in which the taste threshold is linked to the haplotype of specific receptors (Kim et al., 2004). Recent observation of environmental modulation or plasticity within the human taste system are therefore surprising (Kobayashi and Kennedy, 2002; Kobayashi et al., 2006) because this was thought to not occur.

Conversely, in pathology, taste thresholds are frequently altered, although these symptoms are not often investigated (Miller and Naylor, 1989). Altered taste has been reported in depression and anxiety, but there has been little investigation of the chemosensory deficit, which seems surprising given the potential impact on quality of life (Miller and Naylor, 1989). Severely depressed patients have decreased sensitivity to all tastes, especially sweet (Steiner et al., 1969), which normalizes on recovery, and they also report lower-intensity responses to suprathreshold stimuli (Amsterdam et al., 1987). In panic disorder patients, there is reduced quinine sensitivity (DeMet et al., 1989), whereas induced stress in normal individuals increases sensitivity to the bitter taste of saccharin (Dess and Edelheit, 1998).

The "monoamine theory of depression" suggests that depres-

Received Aug. 10, 2006; revised 0ct. 26, 2006; accepted 0ct. 26, 2006.

This work was supported by the Department of Physiology (University of Bristol, Bristol, UK), the Medical Research Council UK, and the Avon and Wiltshire Mental Health Partnership NHS Trust.

Correspondence should be addressed to Dr. Lucy F. Donaldson, Department of Physiology, School of Medical Sciences, University of Bristol, University Walk, Bristol BS8 1TD, UK. E-mail: Lucy.Donaldson@bris.ac.uk. D01:10.1523/JNEUROSCI.3459-06.2006

Copyright $\odot 2006$ Society for Neuroscience $\quad$ 0270-6474/06/2612664-08\$15.00/0 sion is a consequence of diminished circulating monoamine concentrations and hence neurotransmission of noradrenaline (NA), dopamine, and serotonin (5-HT), and/or a reduction in the sensitivity of their receptors (Hirschfeld, 2000). Many antidepressants modulate monoamine function, and their use is associated with dysgeusia (Deems et al., 1991; Schiffman et al., 2000). This modulation of monoamine function may have an impact on taste perception, and this may be the basis for altered taste in affective disorders.

The strongest evidence for an involvement of 5-HT and NA in taste signaling is at the level of the taste bud: taste cells from many species express 5-HT (Nada and Hirata, 1975; Kim and Roper, 1995; Clapp et al., 2004), its synthetic enzymes (DeFazio et al., 2006), and its receptors (Delay et al., 1997), and both take up 5-HT (Nagai et al., 1998) and release it in response to stimulation with tastants (Huang et al., 2005). 5-HT and NA affect taste cell excitability by altering ion channel function (Herness and Chen, 1997; Herness and Chen, 2000; Herness et al., 2002). 5-HT modulates responses in primary gustatory neurons (Esakov et al., 1983), possibly through $5-\mathrm{HT}_{3}$ receptors (Zhong et al., 1999; Wang et al., 2002). Evidence for 5-HT and NA signaling in higher centers is less strong, but serotonergic neurotransmission has been identified in the gustatory nucleus of the solitary tract and thalamus (Thor et al., 1988; Lavoie and Parent, 1991).

We have investigated plasticity in the normal human taste system by modulating systemic monoamines using acute doses of specific monoamine reuptake inhibitors and the possible link between mood, 5-HT and NA, and taste.

\section{Materials and Methods}

Twenty healthy Caucasians (12 males, 8 females), 19-47 years of age, were recruited for this study. One subject only completed part of the 
A
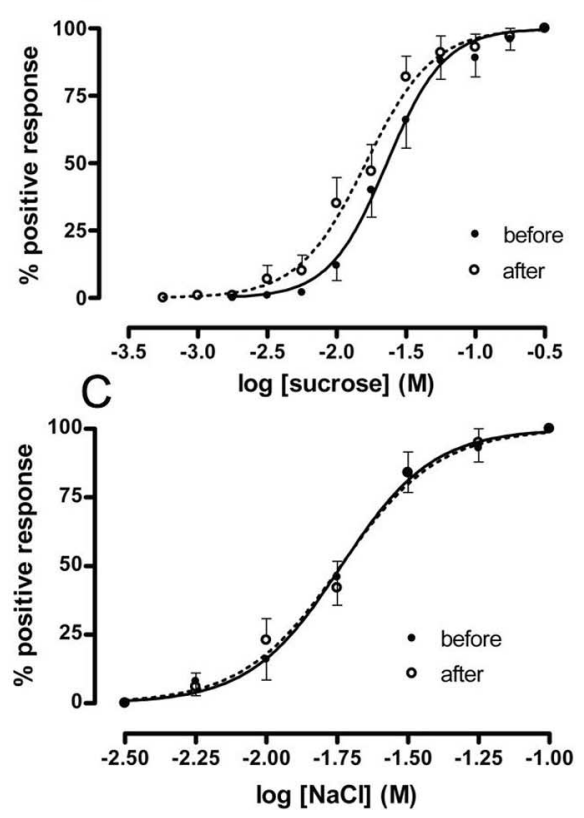

Figure 1. Effect of 5-HT enhancement on taste threshold. Taste psychophysical functions are shown before (filled circles and solid lines) and after (open circles and dotted lines) SSRI. SSRI (paroxetine) administration significantly increased sweet $(\boldsymbol{A})$ taste sensitivity $(p<0.001)$ and bitter $(\boldsymbol{B})$ taste sensitivity $(p<0.0001)$ but had no effect on salt $(\boldsymbol{C})$ or sour $(\boldsymbol{D})$ taste sensitivity. Taste acuity (slope of the line) was unaffected by SSRI administration. Data shown are mean \pm SEM.

study because of personal time constraints. All subjects gave informed consent, and protocols were approved by the University of Bath Local Ethics Committee. Subjects were asked to refrain from consuming alcohol the day before testing, caffeine on the day of testing, and food during the experimentation period. Criteria for inclusion in the study were that subjects were medically fit, have no previous history of depression or anxiety, and were not users of psychotropic medication, either prescribed or recreational. Subjects were excluded if their caffeine and alcohol consumption exceeded six strong cups per day or $>30-50$ units per week (female/male), respectively, or if they were smokers, because smoking alters taste perception (Sato et al., 2002).

Protocols for each taste test. At each visit, the subjects completed the Spielberger State and Trait (Spielberger et al., 1983) and Beck Depression Inventories (Beck et al., 1961) before testing began. Taste responses to sweet, salt, bitter, and sour stimuli were then determined. Subjects were informed of which taste modality (sweet, bitter, salt, or sour) they were receiving but were given no indication of whether the tester thought they would be able to recognize the taste or not. Low concentrations of one tastant may be misidentified as another (Pilkova et al., 1991); to avoid this potential confounding effect, subjects were informed as to the taste stimulus. In addition, detection thresholds (i.e., the ability to detect the presence of a tastant, rather than what the taste is), although often lower than recognition thresholds, are also more variable between subjects (Gomez et al., 2004). Tastants were applied in solution to the tip of the tongue, using a cotton bud saturated with the solution at room temperature, and placed on the tongue for $\sim 5 \mathrm{~s}$ (Prutkin et al., 1999). Without closing their mouths, the subjects were asked to indicate whether or not they could taste the stimulus at that concentration. Between each stimulus application, a $20 \mathrm{~s}$ interstimulus interval was adhered to, during which time the subjects would rinse their mouths with $\sim 25 \mathrm{ml}$ of deionized water. Each concentration of stimulus was presented to the subject five times in total, and the percentage of positive responses at each concentration could therefore be determined. Subjects were first presented with a solution that should be above threshold; thereafter, stimuli were presented in a pseudorandom order in concentrations representing $1 / 4$ log steps between the lowest (undetectable, $0 \%$ detection) and the highest (always detectable, 100\% detection) concentrations, with each concentration being presented five times. This protocol was adopted to min- imize both adaptation to the stimulus and guessing by the subject. The range of concentrations varied for different modalities as follows: sweet ( $300 \mathrm{~mm}$ to $300 \mu \mathrm{M}$ sucrose), bitter (300$0.3 \mu \mathrm{M}$ quinine hydrochloride), salt (100-0.2 $\mathrm{mm} \mathrm{NaCl}$ ), and sour $(100-0.56 \mathrm{~mm} \mathrm{HCl})$. Solutions were prepared shortly before testing and kept refrigerated at $4^{\circ} \mathrm{C}$ between trials.

Over three visits, psychophysical taste functions were determined before and $2 \mathrm{~h}$ after administration of a 5-HT-specific reuptake inhibitor (SSRI; $20 \mathrm{mg}$ of paroxetine), an NA reuptake inhibitor (NARI; $4 \mathrm{mg}$ of reboxetine), or an inactive placebo (lactose). Drug administration was randomized and was double blind with respect to the active drugs and single blind for the placebo arm. Measurements of alertness, sleepiness, nausea, and anxiety were taken before and after each taste determination using $1-100$ visual analog scales (VASs).

Taste psychometric functions based on percentage of positive taste recognition against log solute concentration were generated for each individual at each visit (see Fig. 4) to determine individual response to drug intervention. Taste psychometric functions before and after drug administration were also determined for the entire group of 20 subjects. From these curves, taste recognition thresholds (the concentration at which the subject would recognize the taste $50 \%$ of the time) were calculated before and after each treatment to determine the degree of change in taste recognition that occurred.

Statistical analysis. The percentage of positive results for all of the subjects was plotted against the log concentrations of the taste solutions before and after drug and placebo treatments. All statistical comparisons were performed using GraphPad Prism version 4 (GraphPad Software, San Diego, CA). Standard sigmoidal stimulus-response curves of percentage of correct taste identification versus $\log _{10}$ tastant concentration (molar) were used to compare sensory thresholds (defined as the concentration at which the taste could be recognized $50 \%$ of the time) to internal baseline (predrug) values using an $F$ test. The correlation between the subjects' anxiety and depression levels and both baseline taste thresholds and the change in taste recognition threshold after drug were determined using a Spearman's correlation analysis. Median split data were compared using a Mann-Whitney $U$ test, and comparisons of VAS scores of different tastes before and after drug were performed using a Wilcoxon signed rank test.

\section{Results}

\section{Effects of monoamine manipulation on taste perception}

Consistent with the presence of 5-HT in taste buds and throughout the gustatory system, administration of an acute dose of paroxetine (an SSRI) significantly modulated human taste perception. Paroxetine (modulation of 5-HT) increased both sweet and bitter taste sensitivity, reducing taste thresholds by 27 and $53 \%$, respectively (Fig. 1, Table 1). There was no significant effect on either sour or salt taste sensitivity (Fig. 1). The slopes of the curves, indicating the range of concentrations over which subjects could detect a change in the concentration of tastant in the solutions (taste acuity), were unaffected by 5 -HT modulation (Table 2). Quinine can be transduced through both a receptor/ phospholipase $\mathrm{C} \beta$ (PLC $\beta$ ) pathway common to sweet, bitter, and umami taste (described below) and, at high concentrations, through a PLC-independent pathway (Dotson et al., 2005). In two subjects, therefore, the effect of paroxetine on propylthioura- 
Table 1. Taste recognition thresholds for the four basic taste modalities

\begin{tabular}{|c|c|c|c|c|c|c|c|c|c|}
\hline Taste & Before placebo & After placebo & $\%$ Change & Before SSRI & After SSRI & $\%$ Change & Before NARI & After NARI & $\%$ Change \\
\hline Bitter & $\begin{array}{l}54 \mu \mathrm{M} \\
(36-79 \mu \mathrm{M})\end{array}$ & $\begin{array}{l}63 \mu \mathrm{M} \\
(41-94 \mu \mathrm{m})\end{array}$ & $16 \%$ Increase & $\begin{array}{l}30 \mu \mathrm{m}^{\ddagger} \\
(24-38 \mu \mathrm{M})\end{array}$ & $\begin{array}{l}14 \mu \mathrm{m}^{\dagger} \\
(12-19 \mu \mathrm{m})\end{array}$ & $\begin{array}{l}53 \% \\
\text { Decrease }^{\dagger}\end{array}$ & $\begin{array}{l}31 \mu \mathrm{m}^{\ddagger} \\
(24-39 \mu \mathrm{m})\end{array}$ & $\begin{array}{l}19 \mu \mathrm{m}^{*} \\
(15-26 \mu \mathrm{m})\end{array}$ & $\begin{array}{l}39 \% \\
\text { Decrease }^{*}\end{array}$ \\
\hline Sweet & $\begin{array}{l}44 \mathrm{~mm} \\
(36-53 \mathrm{~mm})\end{array}$ & $\begin{array}{l}41 \mathrm{~mm} \\
(34-49 \mathrm{~mm})\end{array}$ & 7\% Decrease & $\begin{array}{l}23.4 \mathrm{~mm}^{\ddagger} \\
(21-28 \mathrm{~mm})\end{array}$ & $\begin{array}{l}17 \mathrm{~mm}^{* * *} \\
(14-19 \mathrm{~mm})\end{array}$ & $\begin{array}{l}27 \% \\
\text { Decrease }\end{array}$ & $\begin{array}{l}26 \mathrm{~mm}^{\ddagger} \\
(22-30 \mathrm{~mm})\end{array}$ & $\begin{array}{l}22 \mathrm{~mm} \\
(18-25 \mathrm{~mm})\end{array}$ & $\begin{array}{l}15 \% \\
\text { Decrease }\end{array}$ \\
\hline Salt & $\begin{array}{l}29 \mathrm{~mm} \\
(21-37 \mathrm{~mm})\end{array}$ & $\begin{array}{l}26 \mathrm{~mm} \\
(19-33 \mathrm{~mm})\end{array}$ & $10 \%$ Decrease & $\begin{array}{l}19 \mathrm{~mm}^{\ddagger} \\
(16-21 \mathrm{~mm})\end{array}$ & $\begin{array}{l}19 \mathrm{~mm} \\
(18-24 \mathrm{~mm})\end{array}$ & & $\begin{array}{l}21 \mathrm{~mm}^{\ddagger} \\
(20-26 \mathrm{~mm})\end{array}$ & $23 \mathrm{~mm}$ & $\begin{array}{l}9 \% \\
\text { Increase }\end{array}$ \\
\hline Sour & $\begin{array}{l}9 \mathrm{~mm} \\
(7-13 \mathrm{~mm})\end{array}$ & $\begin{array}{l}9 \mathrm{~mm} \\
(8-13 \mathrm{~mm})\end{array}$ & & $\begin{array}{l}10 \mathrm{~mm} \\
(8-11 \mathrm{~mm})\end{array}$ & $\begin{array}{l}8 \mathrm{~mm} \\
(6-9 \mathrm{~mm})\end{array}$ & $\begin{array}{l}20 \% \\
\text { Decrease }\end{array}$ & $\begin{array}{l}9 \mathrm{~mm} \\
(8-10 \mathrm{~mm})\end{array}$ & $\begin{array}{l}7 \mathrm{~mm}^{*} \\
(6-8 \mathrm{~mm})\end{array}$ & $\begin{array}{l}22 \% \\
\text { Decrease* }\end{array}$ \\
\hline
\end{tabular}

Data shown are means (95\% confidence intervals). Statistical comparisons of the threshold values were compared to baseline values using an $F$ test: ${ }^{*} p<0.05,{ }^{* *} p<0.01,{ }^{* * *} p<0.001$, and ${ }^{\dagger} p<0.0001$ compared with baseline responses; ${ }_{p}^{\ddagger}<0.05$ compared with before placebo thresholds.

Table 2. Taste acuity measurements (slope of curve) for the four basic taste modalities

\begin{tabular}{|c|c|c|c|c|c|c|}
\hline Taste & Before placebo $\left(\% \mathrm{~mm}^{-1}\right)$ & After placebo $\left(\% \mathrm{~mm}^{-1}\right)$ & Before SSRI $\left(\% \mathrm{~mm}^{-1}\right)$ & After SSRI (\%mm $\left.{ }^{-1}\right)$ & Before NARI $\left(\% \mathrm{~mm}^{-1}\right)$ & After NARI $\left(\% \mathrm{~mm}^{-1}\right)$ \\
\hline Bitter & 1.05 & 1.02 & & & 1.1 & 0.9 \\
\hline Sweet & $\begin{array}{l}(0.5-1.0) \\
2 \\
(1-3)\end{array}$ & $\begin{array}{l}(0.5-1.6) \\
2.3 \\
(1.1-3.5)\end{array}$ & $\begin{array}{l}(0.8-1.3) \\
2.1 \\
(1.6-2.6)\end{array}$ & $\begin{array}{l}(0 . /-1.2) \\
1.8 \\
(1.4-2.2)\end{array}$ & $\begin{array}{l}(0.9-1.4) \\
2 \\
(1.5-2.5)\end{array}$ & $\begin{array}{l}(0.7-1.1) \\
2.1 \\
(1.5-2.6)\end{array}$ \\
\hline Salt & $\begin{array}{l}1.5 \\
(0.3-2.7)\end{array}$ & $\begin{array}{l}1.4 \\
(0.3-2.5)\end{array}$ & $\begin{array}{l}2.7 \\
(1.8-3.6)\end{array}$ & $\begin{array}{l}2.5 \\
(1.7-3.3)\end{array}$ & $\begin{array}{l}2.4 \\
(1.7-3.1)\end{array}$ & $\begin{array}{l}3.3 \\
(2.2-4.3)\end{array}$ \\
\hline Sour & $\begin{array}{l}1.2 \\
(0.5-1.9)\end{array}$ & $\begin{array}{l}1.8 \\
(0.8-2.8)\end{array}$ & $\begin{array}{l}1.7 \\
(1.2-2.1)\end{array}$ & $\begin{array}{l}2 \\
(1.4-2.5)\end{array}$ & $\begin{array}{l}2.4 \\
(1.8-3)\end{array}$ & $\begin{array}{l}2.2 \\
(1.6-2.7)\end{array}$ \\
\hline
\end{tabular}

The value represents the increase in identification (percentage correct response) per millimolar change in concentration. Data shown are means ( $95 \%$ confidence intervals). There were no statistical differences.

cil (PROP) taste was also examined. Paroxetine caused a dramatic shift in PROP threshold in one of these individuals (subject $1,12 \rightarrow 4 \mu \mathrm{M})$ with no effect on salt taste $(25 \rightarrow 24 \mathrm{~mm})$. The second individual showed a much smaller drop in PROP threshold (subject 2, 36 $\rightarrow 29 \mu \mathrm{M}$ ), but interestingly, additional analysis of the data obtained with quinine showed that subject 2 had little change in threshold to quinine taste after paroxetine $(23 \rightarrow 24 \mu \mathrm{M})$, whereas subject 1, as with PROP, had lowered quinine thresholds $(210 \rightarrow 87 \mu \mathrm{M})$ after paroxetine. This indicates that, although there is some variation in response among individuals (see Fig. 4C), modulation of bitter taste by $5-\mathrm{HT}$ is consistent across individuals, regardless of the taste stimulus used. In both subjects, PROP thresholds were not different $24 \mathrm{~h}$ after paroxetine compared with those before drug administration.

There was some variation in baseline taste recognition thresholds between test sessions (Table 1). We always included a baseline threshold test with each drug to control for this potential variation in threshold between days. We have no explanation for the variation in baselines observed; it is possible that this observation is attributable to some environmental influence on taste. Placebo had no significant effect on either detection thresholds or acuity for any taste modality when compared with these measures before placebo (Fig. 2, Table 2).

Enhancement of NA levels also increased taste sensitivity, but in the case of this manipulation, the effect was seen as a lowering of taste thresholds to bitter (by 39\%) and sour (by 22\%) tastes. The effect on sour taste was much less pronounced than that on bitter taste (Fig. 3, Table 1). Again, there was no significant effect of NARI administration on taste acuity. There was also no significant effect of NARI
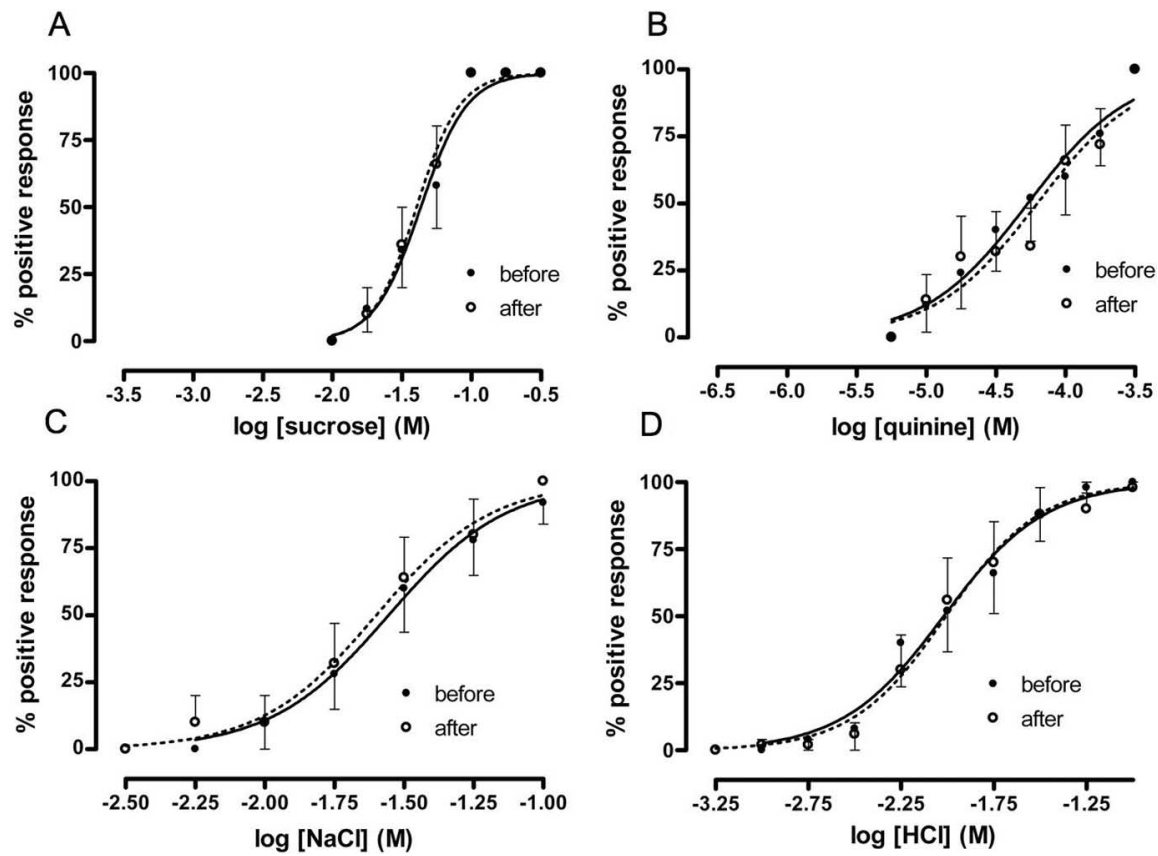

Figure 2. Effect of placebo on taste threshold. Taste psychophysical functions are shown before (filled circles and solid lines) and after (open circles and dotted lines) placebo. Placebo administration did not affect taste sensitivity or acuity for sweet $(\boldsymbol{A})$, bitter $(\boldsymbol{B})$, salt $(\boldsymbol{C})$, or sour $(\boldsymbol{D})$ taste. Data shown are mean \pm SEM.

administration on either sweet or salt taste. In fact, it is worth noting that there were no effects of any drug on salt taste (Figs. 1-3), enabling salt taste to be used as a robust internal control for the reproducibility of our data within and between test visits.

One powerful, serendipitous finding of this study was that we could study the effect of manipulation of monoamine neurotransmitters in an individual subject. Baseline psychophysical functions could be plotted and compared for each individual for each taste (Fig. 4A) and show robust changes in taste thresholds in response to monoamine manipulation (Fig. $4 C$ ). As with the 
A
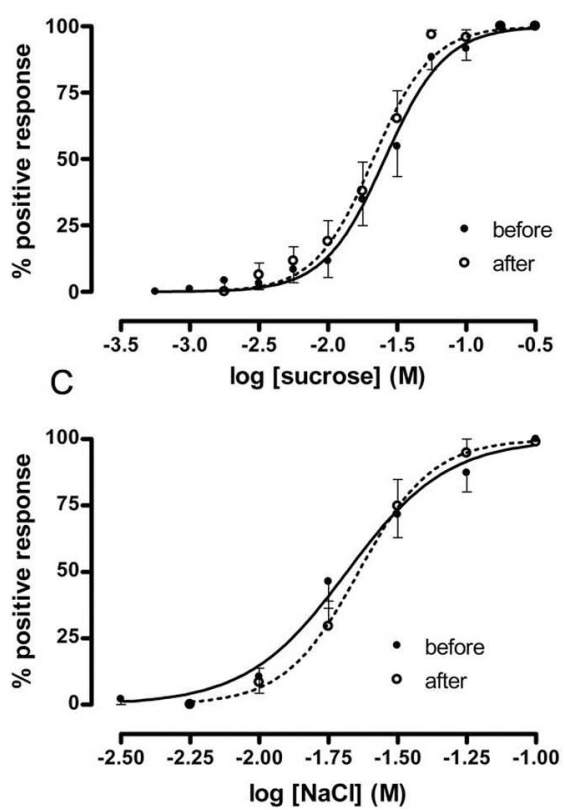

B
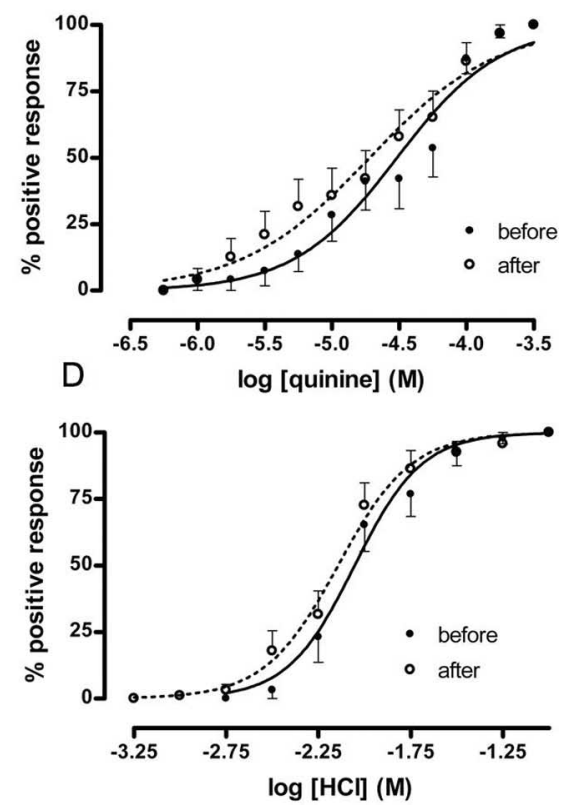

Figure 3. Effect of NA enhancement on taste threshold. Taste psychophysical functions are shown before (filled circles and solid lines) and after (open circles and dotted lines) NARI. $\boldsymbol{A}, \boldsymbol{B}$, NARI administration had no effect on sweet taste sensitivity $(\boldsymbol{A})$ but significantly increased bitter taste sensitivity $(\boldsymbol{B})(p<0.0001) . \boldsymbol{C}, \boldsymbol{D}$, Salt taste sensitivity was unaffected $(\boldsymbol{C})$, but sour taste sensitivity was slightly enhanced after NARI administration $(\boldsymbol{D})(p<0.02)$. Taste acuity for all tastes was unaffected. Data shown are mean \pm SEM.

A

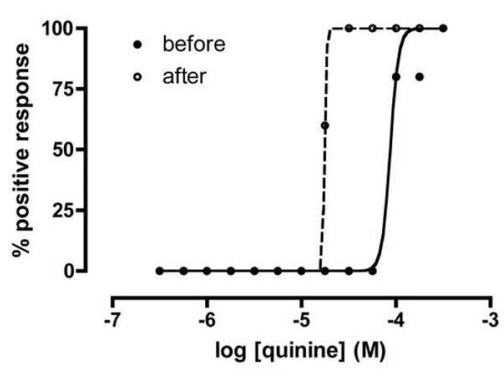

C

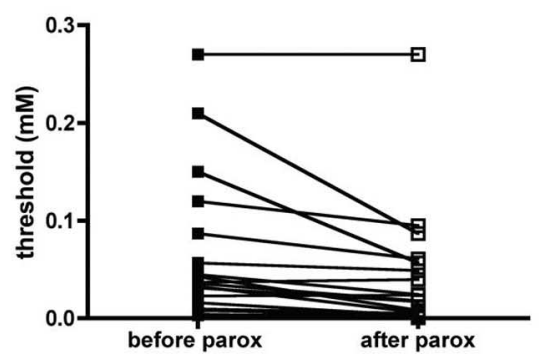

B

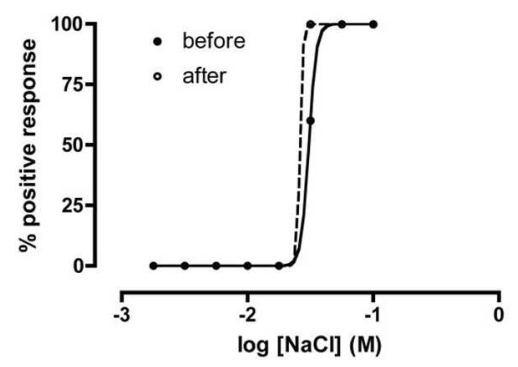

D

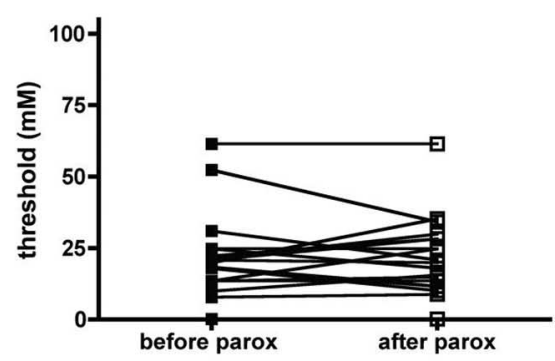

Figure 4. The effects of monoamine manipulation in individuals. $A$, Taste psychophysical functions in a single individual in response to reboxetine (NARI), which significantly reduced bitter tastethreshold in this individual, reducing thresholds by $80 \%$ from $0.9 \mu \mathrm{m}$ to $0.17 \mu \mathrm{m}$ $(p<0.0001) . \boldsymbol{B}$, In the same subject, on the same day, reboxetine did not affect salt taste threshold. $\boldsymbol{C}, \boldsymbol{D}$, When comparing all individual responses before and after drug, monoamine manipulation with paroxetine (parox; SSRI) ( $\boldsymbol{C}$ clearly showed decreases in bitter taste threshold after drug, whereas there was no clear change in salt taste threshold in most individuals with the same drug (D).

group data, individuals showed little change in salt taste even when other tastes varied enormously with the same treatment (Fig. $4 B, D$ ).

There were no significant effects of the drugs on subjects' feelings of alertness, sleepiness, nausea, or anxiety either before, during, or after any of the tests (data not shown).

Thus, bitter taste sensitivity was increased by enhancement of both 5-HT and NA, sweet taste sensitivity was only increased by $5-\mathrm{HT}$, and sour taste was only increased by NA enhancement. This indicates that normal levels of these neurotransmitters determine normal taste thresholds and enhancement increases taste sensitivity in a taste-modality-specific manner.

\section{A peripheral model for SSRI/NARI modulation of taste}

Our finding that manipulation of 5-HT principally affected sweet and bitter tastes, which share a common transduction cascade (Zhang et al., 2003), led us to postulate a mechanism through which modulation of taste could occur. A model of serotonergic transmission in taste buds has been recently formulated and presented by Huang and Roper and their colleagues (Y. J. Huang et al., 2006; Roper, 2006). This model (points 1-3 below), along with our modifications (points 4 and 5), is summarized in Figure 7 and explained below (numbers refer to the encircled numbers in Fig. 7).

(1) Activation of specific G-proteincoupled receptors at the apical membrane of receptor cells activates a common signal transduction pathway (Zhang et al., 2003), consisting of activation of $\mathrm{PLC} \beta_{2}$ through the $\alpha$-gustducin-associated $\beta / \gamma$ subunits $\mathrm{G}_{3} / \mathrm{G}_{13}$ and $\mathrm{Ca}^{2+}$ release from $\mathrm{Ca}^{2+}$ stores through the inositol triphosphate receptor 3 (Perez et al., 2003). Increased intracellular calcium activates the store-operated taste cell-specific TrpM5 receptor (Perez et al., 2002). The receptor cells that transduce taste signals through the PLC $\beta_{2}$ pathway are a different subset of taste cells from those with synaptic machinery, and it is thought unlikely that they communicate directly with gustatory afferents (Clapp et al., 2006; DeFazio et al., 2006).

(2) The increase in intracellular $\mathrm{Ca}^{2+}$ concentration stimulates the release of ATP (Y. J. Huang et al., 2006), a neurotransmitter that has been proposed to be fundamental to bitter taste transmission (Finger et al., 2005). ATP may activate $\mathrm{P} 2 \mathrm{X}_{2}$ or $\mathrm{P} 2 \mathrm{X}_{3}$ receptors on gustatory-free nerve endings in the taste bud (Herness and Chen, 1997; Bo et al., 1999; Finger et al., 2005). ATP can also activate purinoceptors expressed on presynaptic cells (trapezoid on presynaptic cell); these are proposed to be $\mathrm{P}_{2} \mathrm{Y}_{2 / 4}$ receptors (Baryshnikov et al., 2003; Bystrova et al., 2006; Y. J. Huang et al., 2006).

(3) Activation of $\mathrm{P} 2 \mathrm{Y}$ receptors results in release of $\mathrm{Ca}^{2+}$ from 
intracellular stores and a subsequent release of 5-HT and/or NA from presynaptic cells (Y. J. Huang et al., 2006; Roper, 2006). It is known that 5-HT release from taste buds is not dependent on calcium influx but on store release (Huang et al., 2005).

(4) We propose a serotonergic feedback from presynaptic to receptor cells where 5 -HT acts via $5-\mathrm{HT}_{1 \mathrm{~A}}$ receptors (Delay et al., 1997; Herness and Chen, 1997; Herness and Chen, 2000; Kaya et al., 2004) to modulate bitter and sweet signaling. In some amphibian taste cells, activation of $5-\mathrm{HT}_{1 \mathrm{~A}}$ receptors is known to increase intracellular calcium levels (Delay et al., 1997), and 5- $\mathrm{HT}_{1 \mathrm{~A}}$ receptors have been shown to affect intracellular calcium in other cell types (Raymond et al., 1992; Khan et al., 1995). 5-HT ${ }_{1 \mathrm{~A}}$ receptors are expressed on a different cell population in the taste bud than 5-HT (Kaya et al., 2004), and 5-HT release occurs from presynaptic and not receptor cells (Y. J. Huang et al., 2006). However, it should also be kept in mind that 5-HT is known to exert many of its effects on the CNS through volume transmission (Verge and Calas, 2000) rather than at synapses, and it is possible that 5-HT may also affect gustatory afferents acting in this manner in the taste bud, as depicted in Figure 7 (filled circles).

(5) Inhibition of 5-HT transporters found on receptor or presynaptic cells (Ren et al., 1999) by SSRI administration (Nagai et al., 1998) would enhance paracrine signaling through 5-HT, resulting in acute changes in taste thresholds to bitter and sweet substances, as we found. This could also possibly explain the taste disturbances (dysgeusia) reported by patients receiving SSRI treatment (Deems et al., 1991).

\section{The relationship between taste and mood}

All subjects fell within the clinically defined healthy range for scores on the Spielberger State and Trait and Beck's Inventory questionnaires (range: Beck's Inventory, 0-63; Spielberger State, 20-41; Spielberger Trait, 20-44), although some subjects did have anxiety scores that were on the high end of the normal range $(>40)$. The Spielberger minimum score is 20 , and the maximum score is 80 .

To determine whether there was a relationship between mood and taste sensitivity, we determined the correlation between the baseline (before drug) taste thresholds for each subject and their anxiety and depression scores. We found a significant positive correlation was found between Spielberger Trait scores (representing general anxiety levels) and both bitter and salt taste thresholds (Fig. $3 \mathrm{~mm} ;>25,18 \pm 6 \mathrm{~mm})$.
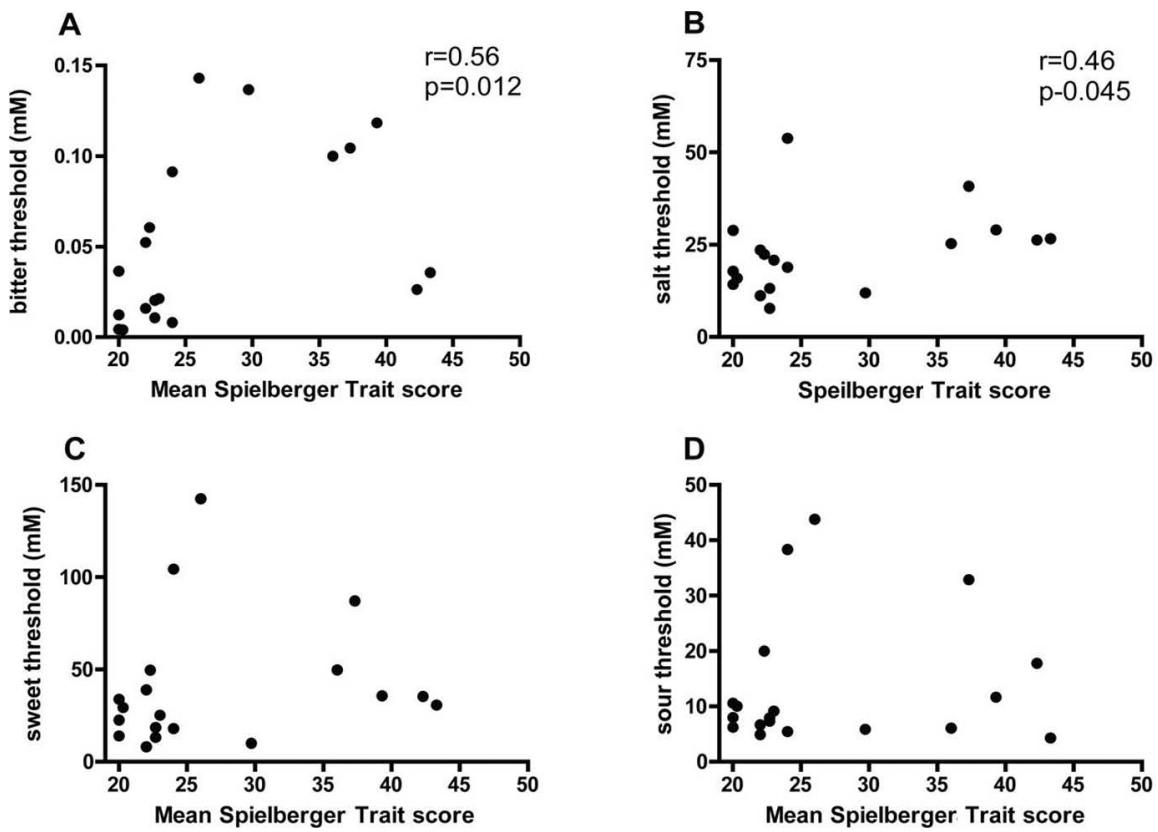

Figure 5. The relationship between general anxiety level and taste thresholds. There is a significant correlation between anxiety level and bitter $(\boldsymbol{A})$ and salt $(\boldsymbol{B})$ baseline taste thresholds, whereas there was no relationship between anxiety and sweet $(\boldsymbol{C})$ or sour (D) threshold. Each data point is the mean of three baseline taste thresholds and corresponding Spielberger Trait scores.
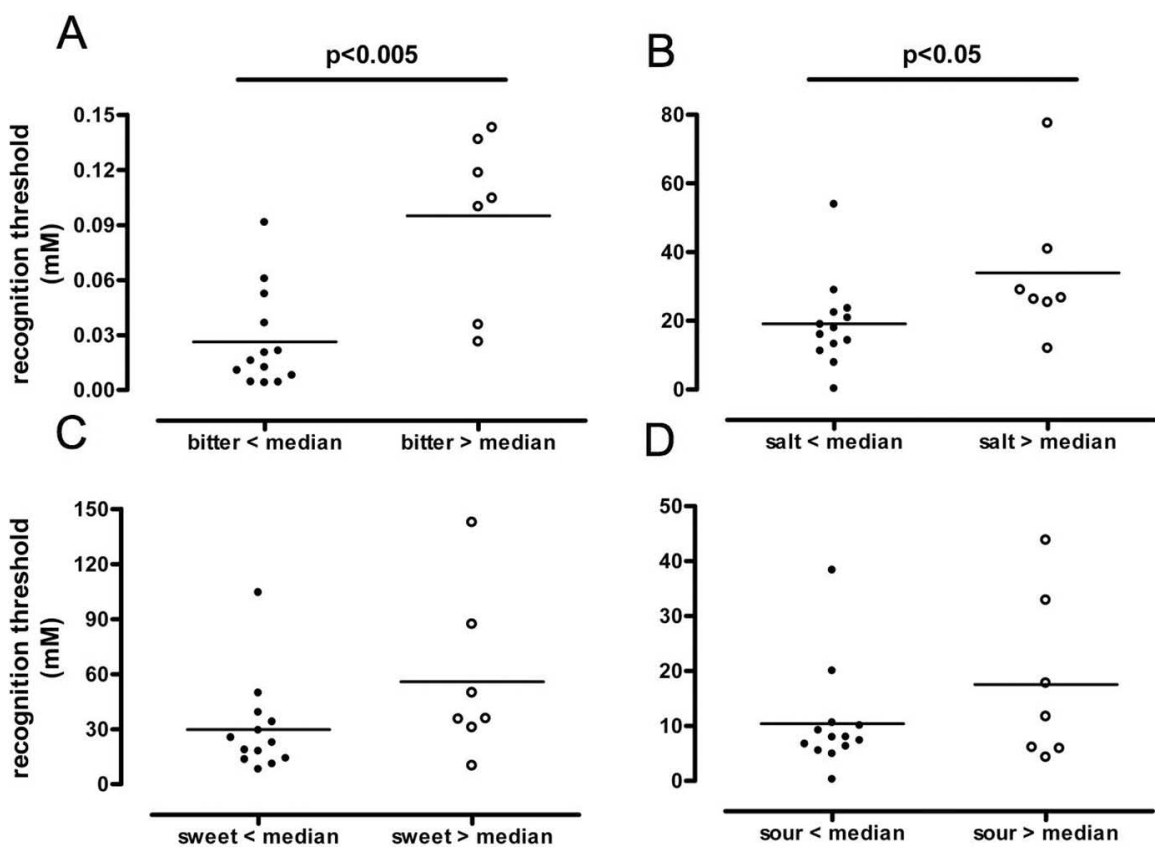

Figure 6. Median split data for bitter and salt threshold showing significantly higher thresholds in the most anxious people. The median value for Spielberger Trait score was 25 , and data were split into those above and below this value for comparison. There was a significant difference between the median split groups for bitter threshold $(A ; 20-25,26 \pm 7 \mu \mathrm{m} ;>25,95 \pm$ $18 \mu \mathrm{m} ; \boldsymbol{p}<0.005)$ and salt threshold $(\boldsymbol{B} ; 20-25,19 \pm 3.5 \mathrm{~mm} ;>25,34 \pm 8 \mathrm{~mm} ; \boldsymbol{p}<0.05)$, whereas there was no significant difference in sweet threshold $(\boldsymbol{C} ; 20-25,30 \pm 7 \mathrm{~mm} ;>25,55 \pm 17 \mathrm{~mm})$ or sour threshold $(\boldsymbol{D} ; 20-25,11 \pm$

5). In other words, in the most anxious people, taste sensations appear to be blunted (taste thresholds are higher). There was no clear relationship between the sweet and sour taste thresholds and either State (anxiety now) or Trait anxiety level. Scores on the Beck's depression questionnaires were all very low, and it was therefore impossible to determine whether there was a relationship between depression and taste in this group. 
Because this relationship suggested that our most anxious volunteers did have different taste thresholds than other subjects in the study, we performed a median split on our data to compare our "anxious" and "non-anxious" subjects' taste thresholds. As seen with the correlations, the "most anxious" subjects had significantly higher bitter and salt taste recognition thresholds than non-anxious subjects (Fig. 6).

\section{Discussion}

Our data show that the taste system is plastic to an extent not previously thought and that 5-HT and NA levels are key in the setting of normal taste thresholds. Disturbance of these transmitters by reuptake inhibition, or in altered mood states in which 5-HT and/or NA may be lowered, alters taste perception. We hypothesized that this would be the case, based on the observations of disturbances of taste both in mood disorder and during antidepressant use. However, there are additional implications of our findings with respect to our understanding of taste transduction and transmission.

Recent observations by two different groups show that there are two distinct populations of cells in circumvallate taste buds, or "receptor cells," that contain the transduction apparatus for sweet, bitter, and umami tastes and "presynaptic cells" that form synapses with gustatory afferents (Clapp et al., 2006; DeFazio et al., 2006). The receptor cells show increases in intracellular calcium in response to tastants. The presynaptic cells do not respond to tastants, but they release 5 - $\mathrm{HT}$ in response to $\mathrm{KCl}$ depolarization (Y. J. Huang et al., 2006).

The effect of SSRI is similar on bitter and sweet tastes, both of which are transduced through a common pathway in receptor cells, and we therefore hypothesize that the effect of 5-HT manipulation on taste occurs at the level of the taste receptor cells rather than in higher centers. Pharmacokinetic study of SSRIs and NARIs show that peak drug plasma concentrations occur at $1-2 \mathrm{~h}$ (Finley, 1994; Hendershot et al., 2001), whereas peak CNS effects, such as sleep disturbance or motor effects, occur 6-8 h after administration (Saletu et al., 1991; Hindmarch, 1997; Loubinoux et al., 2002). This suggests that at $2 \mathrm{~h}$, plasma drug levels are much greater than brain drug levels and peripheral effects may be more pronounced than central effects. We cannot, however, rule out the possibility of the latter contributing to our findings.

\section{5-HT, NA, and taste}

A large body of evidence suggests that 5-HT is used as a neurotransmitter in the taste bud to modulate cellular responses to tastant stimulation even before transmission to the primary afferent gustatory neurons (Herness et al., 2005). In addition to the localization of 5-HT and its synthetic enzymes, transporters, and receptors in taste cells (Kim and Roper, 1995; Delay et al., 1997; Ren et al., 1999; DeFazio et al., 2006) and its release on stimulation of taste cells (Huang et al., 2005), functional work using zinc-deficient mice (which inhibits the formation of 5-HT in taste cells) showed that the animals had decreased sensitivity to bitter tastes (Kondo et al., 1987). This suggests that 5-HT signaling in taste buds is fundamental to normal taste. We have therefore suggested a possible mechanism of serotonergic signaling in the taste bud, based on literature data and our findings, which is summarized in Figure 7. Clearly, this hypothesis requires testing to determine how 5-HT or NA receptor activation could potentially modulate the transduction of sweet and bitter tastes.

Separate populations of receptor cells are thought to transduce sweet, bitter, and umami tastes, and these are different again from cells that transduce salt and sour tastes (A. L. Huang et al.,

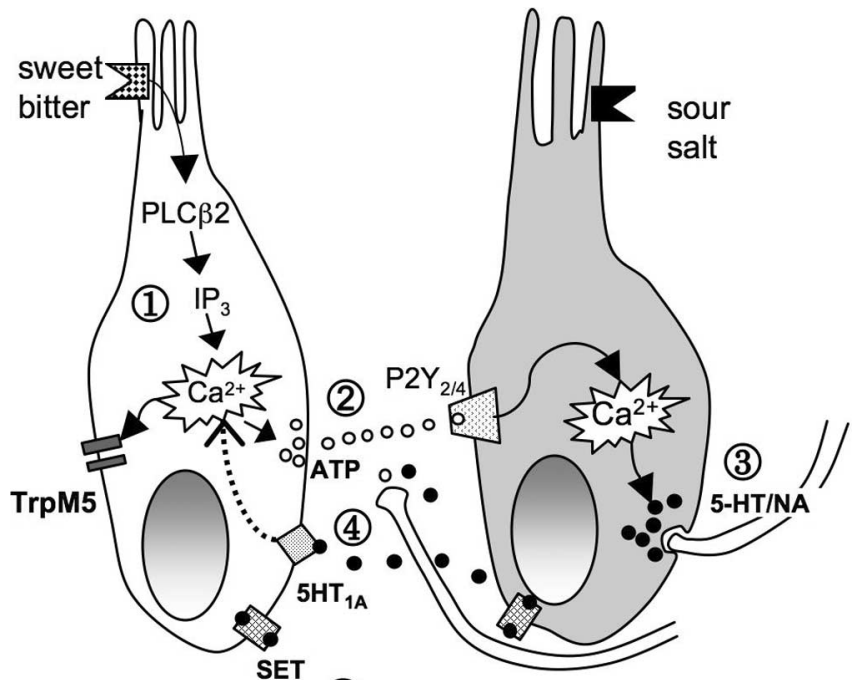

(5)

Receptor cell

"presynaptic cell"

Figure 7. Proposed peripheral mechanism of serotonergic modulation of taste. The model is extended from a model of 5-HT as a neurotransmitter in taste buds, proposed by Roper and colleagues (Y. J. Huang et al., 2006; Roper, 2006), and is fully explained in the text. Receptor cells, which contain the necessary molecules for the transduction of sweet, bitter, and umami tastes, are a separate population from the cells that form synapses with gustatory afferents (presynaptic cells) (Clapp et al., 2006; DeFazio et al., 2006). After transduction of a taste stimulus (1), taste cells release ATP (2), open circles). ATP could directly activate gustatory afferents that are known to express ionotropic purinoreceptors but can also activate purinoceptors on presynaptic cells (trapezoid). This results in release of $\mathrm{Ca}^{2+}$ from intracellular stores in presynaptic cells and a subsequent release of 5 -HT from presynaptic cells (3), filled circles). We propose an additional possible role of 5-HT. When released from presynaptic cells, 5-HT may also act back through volume transmission on taste cells, and/or gustatory afferents to activate 5-HT receptors (4), shaded diamond) and modulate the response to tastants in the taste cell. Inhibition of 5-HT transporters (SET; (5), hatched rectangle) on taste cells by our SSRI administration and the subsequent enhancement of $5-\mathrm{HT}$ signaling could therefore enhance the taste of bitter and sweet substances, as we found. NA could act as either a transmitter released onto gustatory afferents in response to stimulation of presynaptic cells or a modulator of ATP action. Open circles, ATP; filled circles, 5- $\mathrm{HT}$; shaded diamond, 5- $\mathrm{HT}_{1 \mathrm{~A}}$ receptor with 5- $\mathrm{HT}$ bound; hatched rectangle, SET transporting $5-\mathrm{HT}$; trapezoid, $\mathrm{P}_{2} \mathrm{Y}_{2 / 4}$ receptor with ATP bound.

2006), which are most likely presynaptic cells (DeFazio et al., 2006). With reference to our model, the lack of effect of SSRIs on salt and sour taste is consistent with 5 -HT being released by presynaptic cells only on activation through receptor cells and not by direct sour or salt stimulation of presynaptic cells.

Exogenous NA also modulates taste cell ion channel function and signaling (Herness et al., 2002) and can affect responses in gustatory afferent nerves (Morimoto and Sato, 1982). It is possible that NARI administration could affect taste in a similar manner to that outlined in our model for 5-HT, because NA and its cognate receptors are also found in mammalian taste cells (Herness et al., 2002). There is less evidence supporting a role for NA in signaling within the taste bud than for 5-HT, but it is clear that taste cells do respond to both $\alpha$ - and $\beta$-adrenoceptor agonists and that NA released within taste buds can modulate taste cell signaling (Herness et al., 2002). Thus, NA could act as a transmitter or modulator of the effect of other transmitters at the gustatory afferent (Fig. 7 and see below) and may be the principle transmitter released from presynaptic cells in response to sour stimulation because only NARI had an effect on this modality.

We find that 5-HT manipulation modulates taste in humans. Finger et al. (2005), in contrast, showed that knock-out of 5- $\mathrm{HT}_{3}$ receptors found on gustatory afferents had no effect on taste 
preference tests in mice, whereas $\mathrm{P} 2 \mathrm{X}_{2 / 3}$ double knock-out completely inhibited taste responses. This has been interpreted as evidence that 5-HT is not involved in peripheral taste processing. The absence of taste effects in the $5-\mathrm{HT}_{3}$ receptor knock-out mice can be completely explained by actions of 5-HT on any one of several other possible 5-HT receptor subtypes that were still present in these animals, such as $5-\mathrm{HT}_{1 \mathrm{~A}}$ receptors (Delay et al., 1997; Herness and Chen, 1997). Evidence is also accumulating that $\mathrm{P} 2 \mathrm{X}_{2}$ receptors interact with $5-\mathrm{HT}_{3}, \mathrm{GABA}_{\mathrm{A}}$, and nicotinic receptors in sensory neurons (Boue-Grabot et al., 2003, 2004). 5 -HT can act through volume transmission (Verge and Calas, 2000 ) in addition to its actions at conventional synapses. Multiple neurotransmitter release, in conjunction with nonsynaptic action of 5-HT [and/or NA or uncharacterized transmitters, e.g., GABA (Obata et al., 1997)] in the taste bud, could also explain the discrepancy between our data and those of Finger et al. (2005). Thus, ATP may be necessary for taste transmission, but its action on gustatory afferents or presynaptic cells may be modulated by corelease of other transmitters such as 5-HT, NA, or GABA (Boue-Grabot et al., 2004).

The finding that the receptors for sweet, bitter, umami (Zhang et al., 2003), and, most recently, sour tastants are expressed in primarily nonoverlapping taste cell populations has led to the recent proposal that taste encoding is through a "labeled-line" rather than an "across-fiber" pattern generation (A. L. Huang et al., 2006). Our model is consistent with this concept. Zuker and colleagues (A. L. Huang et al., 2006) have suggested that activation of the "sweet" or "bitter" receptor cells, rather than taste receptor molecules per se, initiate the transfer of gustatory information to the CNS. It has previously been difficult to conceive how taste could be encoded through a labeled-line pattern, given the rapid turnover of taste cells within the taste bud (Farbman, 1980). How can a continuously remodeling system maintain a labeled-line pattern? If modality-specific gustatory afferents express unique combinations of receptors that correlate with the transmitters released from receptor and/or presynaptic cells, as described above, afferents would always be activated if a specific combination of transmitters were released within the taste bud "signal processing units" (Roper, 2006). In this way, taste receptor cells could specifically activate their cognate gustatory afferents through either paracrine or synaptic effects, or a combination of both (Roper, 2006).

\section{Taste and mood: how anxiety may affect what we eat}

Surprisingly, a relationship between mood and taste has been recognized for many years; taste disturbances, or dysgeusia, are "neglected symptoms of depression" (Miller and Naylor, 1989). Disturbances in taste have not been recognized as a true (patho-) physiological symptom, and little work has been done on the mechanisms through which taste is disturbed in affective disorders.

We found a significant positive correlation between mean trait anxiety scores and mean baseline taste thresholds for bitter and salt. This is, in part, surprising, given that salt thresholds do not alter in response to acute 5-HT or NA manipulation. Previous reports on patients with severe depression requiring hospitalization (Steiner et al., 1969) or seasonal affective disorder (Arbisi et al., 1996), suggested that different taste modalities, including salt, could be affected by these chronic disorders. This implies that long-term modulation of neurotransmitter levels even in minor mood disturbance could affect some tastes, specifically salt, more profoundly than an acute manipulation. Our data suggest that the most anxious people have significantly higher bitter and salt taste thresholds even in the normal healthy population. Taste would therefore appear to be an interesting sensory measure with respect to mood, given our data and complementary studies showing that stress and personality type affect bitterness and sweetness ratings in healthy individuals (Dess and Edelheit, 1998).

In conclusion, our findings show that taste, previously thought to be principally genetically determined with little dayto-day variability, can be extremely plastic and is profoundly affected by modulation of the 5-HT and/or noradrenergic systems in normal healthy individuals. Our results reinforce previously reported findings of taste disturbances in patients with affective disorders, in that taste threshold is directly related to anxiety level, again in a normal healthy population where response bias is likely to be less of a problem than in an ill population. These results support an important and basic role for 5-HT and NA in taste function and may explain why anxious and depressed individuals exhibit diminished appetite.

\section{References}

Amsterdam JD, Settle RG, Doty RL, Abelman E, Winokur A (1987) Taste and smell perception in depression. Biol Psychiatry 22:1481-1485.

Arbisi PA, Levine AS, Nerenberg J, Wolf J (1996) Seasonal alteration in taste detection and recognition threshold in seasonal affective disorder: the proximate source of carbohydrate craving. Psychiatry Res 59:171-182.

Bartoshuk LM (2000) Comparing sensory experiences across individuals: recent psychophysical advances illuminate genetic variation in taste perception. Chem Senses 25:447-460.

Baryshnikov SG, Rogachevskaja OA, Kolesnikov SS (2003) Calcium signaling mediated by $\mathrm{P} 2 \mathrm{Y}$ receptors in mouse taste cells. J Neurophysiol 90:3283-3294.

Beck AT, Ward CH, Mendelson M, Mock J, Erbaugh J (1961) An inventory for measuring depression. Arch Gen Psychiatry 4:561-571.

Bo X, Alavi A, Xiang Z, Oglesby I, Ford A, Burnstock G (1999) Localization of ATP-gated $\mathrm{P} 2 \mathrm{X} 2$ and $\mathrm{P} 2 \mathrm{X} 3$ receptor immunoreactive nerves in rat taste buds. NeuroReport 10:1107-1111.

Boue-Grabot E, Barajas-Lopez C, Chakfe Y, Blais D, Belanger D, Emerit MB, Seguela P (2003) Intracellular cross talk and physical interaction between two classes of neurotransmitter-gated channels. J Neurosci 23:1246-1253.

Boue-Grabot E, Emerit MB, Toulme E, Seguela P, Garret M (2004) Crosstalk and co-trafficking between rhol/GABA receptors and ATP-gated channels. J Biol Chem 279:6967-6975.

Bystrova MF, Yatzenko YE, Fedorov IV, Rogachevskaja OA, Kolesnikov SS (2006) P2Y isoforms operative in mouse taste cells. Cell Tissue Res 323:377-382.

Clapp TR, Yang R, Stoick CL, Kinnamon SC, Kinnamon JC (2004) Morphologic characterization of rat taste receptor cells that express components of the phospholipase $\mathrm{C}$ signaling pathway. J Comp Neurol 468:311-321.

Clapp TR, Medler KF, Damak S, Margolskee RF, Kinnamon SC (2006) Mouse taste cells with $\mathrm{G}$ protein-coupled taste receptors lack voltagegated calcium channels and SNAP-25. BMC Biol 4:7.

Deems DA, Doty RL, Settle RG, Moore-Gillon V, Shaman P, Mester AF, Kimmelman CP, Brightman VJ, Snow Jr JB (1991) Smell and taste disorders, a study of 750 patients from the University of Pennsylvania Smell and Taste Center. Arch Otolaryngol Head Neck Surg 117:519-528.

DeFazio RA, Dvoryanchikov G, Maruyama Y, Kim JW, Pereira E, Roper SD, Chaudhari N (2006) Separate populations of receptor cells and presynaptic cells in mouse taste buds. J Neurosci 26:3971-3980.

Delay RJ, Kinnamon SC, Roper SD (1997) Serotonin modulates voltagedependent calcium current in Necturus taste cells. J Neurophysiol 77:2515-2524.

DeMet E, Stein MK, Tran C, Chicz-DeMet A, Sangdahl C, Nelson J (1989) Caffeine taste test for panic disorder: adenosine receptor supersensitivity. Psychiatry Res 30:231-242.

Dess NK, Edelheit D (1998) The bitter with the sweet: the taste/stress/temperament nexus. Biol Psychol 48:103-119.

Dotson CD, Roper SD, Spector AC (2005) PLCbeta2-independent behav- 
ioral avoidance of prototypical bitter-tasting ligands. Chem Senses 30:593-600.

Esakov AI, Golubtsov KV, Solov'eva NA (1983) Significance of serotonin in the activity of the taste receptor apparatus of the frog Rana temporaria. Zh Evol Biokhim Fiziol 19:62-67.

Farbman AI (1980) Renewal of taste bud cells in rat circumvallate papillae. Cell Tissue Kinet 13:349-357.

Finger TE, Danilova V, Barrows J, Bartel DL, Vigers AJ, Stone L, Hellekant G, Kinnamon SC (2005) ATP signaling is crucial for communication from taste buds to gustatory nerves. Science 310:1495-1499.

Finley PR (1994) Selective serotonin reuptake inhibitors: pharmacologic profiles and potential therapeutic distinctions. Ann Pharmacother 28:1359-1369.

Gomez FE, Cassis-Nosthas L, Morales-de-Leon JC, Bourges H (2004) Detection and recognition thresholds to the 4 basic tastes in Mexican patients with primary Sjogren's syndrome. Eur J Clin Nutr 58:629-636.

Hendershot PE, Fleishaker JC, Lin KM, Nuccio ID, Poland RE (2001) Pharmacokinetics of reboxetine in healthy volunteers with different ethnic descents. Psychopharmacology (Berl) 155:148-153.

Herness MS, Chen Y (2000) Serotonergic agonists inhibit calcium-activated potassium and voltage-dependent sodium currents in rat taste receptor cells. J Membr Biol 173:127-138.

Herness S, Chen Y (1997) Serotonin inhibits calcium-activated K+ current in rat taste receptor cells. NeuroReport 8:3257-3261.

Herness S, Zhao FL, Kaya N, Lu SG, Shen T, Sun XD (2002) Adrenergic signalling between rat taste receptor cells. J Physiol (Lond) 543:601-614.

Herness S, Zhao FL, Kaya N, Shen T, Lu SG, Cao Y (2005) Communication routes within the taste bud by neurotransmitters and neuropeptides. Chem Senses 30 [Suppl 1]:i37-i38.

Hindmarch I (1997) The effects of antidepressants on psychomotor function with particular reference to reboxetine. Eur Neuropsychopharmacol 7[ Suppl 1]:S17-S21; discussion S71-S73.

Hirschfeld RM (2000) History and evolution of the monoamine hypothesis of depression. J Clin Psychiatry 61 [Suppl 6]:4-6.

Huang AL, Chen X, Hoon MA, Chandrashekar J, Guo W, Trankner D, Ryba NJ, Zuker CS (2006) The cells and logic for mammalian sour taste detection. Nature 442:934-938.

Huang YJ, Maruyama Y, Lu KS, Pereira E, Plonsky I, Baur JE, Wu D, Roper SD (2005) Mouse taste buds use serotonin as a neurotransmitter. J Neurosci 25:843-847.

Huang YJ, Maruyama Y, Pereira E, Roper SD (2006) Cell-to-cell communication in taste buds: the role of ATP and 5HT. Paper presented at 28th Annual Meeting of the Association for Chemoreception Sciences, Sarasota, FL, April.

Kaya N, Shen T, Lu SG, Zhao FL, Herness S (2004) A paracrine signaling role for serotonin in rat taste buds: expression and localization of serotonin receptor subtypes. Am J Physiol Regul Integr Comp Physiol 286:R649-R658.

Khan NA, Ferriere F, Deschaux P (1995) Serotonin-induced calcium signaling via 5-HT1A receptors in human leukemia (K 562) cells. Cell Immunol 165:148-152.

Kim DJ, Roper SD (1995) Localization of serotonin in taste buds: a comparative study in four vertebrates. J Comp Neurol 353:364-370.

Kim UK, Breslin PA, Reed D, Drayna D (2004) Genetics of human taste perception. J Dent Res 83:448-453.

Kobayashi C, Kennedy LM (2002) Experience-induced changes in taste identification of monosodium glutamate. Physiol Behav 75:57-63.

Kobayashi C, Kennedy LM, Halpern BP (2006) Experience-induced changes in taste identification of monosodium glutamate (MSG) are reversible. Chem Senses 31:301-306.

Kondo I, Watanabe Y, Ito Y, Hisada T (1987) A histochemical study of APUD ability in the taste buds of experimentally induced zinc-deficient mice. J Oral Pathol 16:13-17.

Lavoie B, Parent A (1991) Serotoninergic innervation of the thalamus in the primate: an immunohistochemical study. J Comp Neurol 312:1-18.

Loubinoux I, Pariente J, Boulanouar K, Carel C, Manelfe C, Rascol O, Celsis
P, Chollet F (2002) A single dose of the serotonin neurotransmission agonist paroxetine enhances motor output: double-blind, placebocontrolled, fMRI study in healthy subjects. NeuroImage 15:26-36.

Miller SM, Naylor GJ (1989) Unpleasant tast-a neglected symptom in depression. J Affect Disord 17:291-293.

Morimoto K, Sato M (1982) Role of monoamines in afferent synaptic transmission in frog taste organ. Jpn J Physiol 32:855-871.

Nada O, Hirata K (1975) The occurrence of the cell type containing a specific monoamine in the taste bud of the rabbit's foliate papila. Histochemistry 43:237-240.

Nagai T, Delay RJ, Welton J, Roper SD (1998) Uptake and release of neurotransmitter candidates, $[3 \mathrm{H}]$ serotonin, $[3 \mathrm{H}]$ glutamate, and $[3 \mathrm{H}]$ gammaaminobutyric acid, in taste buds of the mudpuppy, Necturus maculosus. J Comp Neurol 392:199-208.

Obata H, Shimada K, Sakai N, Saito N (1997) GABAergic neurotransmission in rat taste buds: immunocytochemical study for GABA and GABA transporter subtypes. Brain Res Mol Brain Res 49:29-36.

Perez CA, Huang L, Rong M, Kozak JA, Preuss AK, Zhang H, Max M, Margolskee RF (2002) A transient receptor potential channel expressed in taste receptor cells. Nat Neurosci 5:1169-1176.

Perez CA, Margolskee RF, Kinnamon SC, Ogura T (2003) Making sense with TRP channels: store-operated calcium entry and the ion channel Trpm5 in taste receptor cells. Cell Calcium 33:541-549.

Pilkova L, Novakova M, Pokorny J (1991) Naming and identification of tastes in aqueous solutions. Nahrung 35:999-1002.

Prutkin JM, Fast K, Lucchina LA, Snyder DJ, Bartoshuk LM (1999) Spatial taste testing and genetic taste variation. Chem Senses 24: 604.

Raymond JR, Albers FJ, Middleton JP (1992) Functional expression of human 5-HT1A receptors and differential coupling to second messengers in CHO cells. Naunyn Schmiedebergs Arch Pharmacol 346:127-137.

Ren Y, Shimada K, Shirai Y, Fujimiya M, Saito N (1999) Immunocytochemical localization of serotonin and serotonin transporter (SET) in taste buds of rat. Brain Res Mol Brain Res 74:221-224.

Roper SD (2006) Cell communication in taste buds. Cell Mol Life Sci 63:1494-1500

Saletu B, Frey R, Krupka M, Anderer P, Grunberger J, See WR (1991) Sleep laboratory studies on the single-dose effects of serotonin reuptake inhibitors paroxetine and fluoxetine on human sleep and awakening qualities. Sleep 14:439-447.

Sato K, Endo S, Tomita H (2002) Sensitivity of three loci on the tongue and soft palate to four basic tastes in smokers and non-smokers. Acta Otolaryngol Suppl:74-82.

Schiffman SS, Zervakis J, Suggs MS, Budd KC, Iuga L (2000) Effect of tricyclic antidepressants on taste responses in humans and gerbils. Pharmacol Biochem Behav 65:599-609.

Spielberger CD, Gorsuch RL, Lushene PR, Vagg PR, Jacobs AG (1983) Manual for the state-trait anxiety inventory (Form Y, ed). Palo Alto, CA: Consulting Psychologists.

Steiner JE, Rosenthal-Zifroni A, Edelstein EL (1969) Taste perception in depressive illness. Isr Ann Psychiatr Relat Discip 7:223-232.

Thor KB, Hill KM, Harrod C, Helke CJ (1988) Immunohistochemical and biochemical analysis of serotonin and substance $\mathrm{P}$ colocalization in the nucleus tractus solitarii and associated afferent ganglia of the rat. Synapse 2:225-231.

Verge D, Calas A (2000) Serotoninergic neurons and serotonin receptors: gains from cytochemical approaches. J Chem Neuroanat 18:41-56.

Wang ZY, Keith IM, Olson Jr EB, Vidruk EH, Bisgard GE (2002) Expression of 5-HT3 receptors in primary sensory neurons of the petrosal ganglion of adult rats. Auton Neurosci 95:121-124.

Zhang Y, Hoon MA, Chandrashekar J, Mueller KL, Cook B, Wu D, Zuker CS, Ryba NJ (2003) Coding of sweet, bitter, and umami tastes: different receptor cells sharing similar signaling pathways. Cell 112:293-301.

Zhong H, Zhang M, Nurse CA (1999) Electrophysiological characterization of 5-HT receptors on rat petrosal neurons in dissociated cell culture. Brain Res 816:544-553. 